\title{
Apoptosis factors caspases and p53 and their impact in chronic rhinosinusitis with nasal polyposis
}

Fabiana Valera ${ }^{1 *}$, Daniel S Küpper ${ }^{2}$, Rafael Malinsky² Cristiane Milanezi $^{3}$, João S Silva ${ }^{3}$, Edwin Tamashiro², Wilma T Anselmo-Lima²

From 9th Symposium of Experimental Rhinology and Immunology of the Nose (SERIN 2013) Leuven, Belgium. 21-23 March 2013

\section{Background}

The inflammatory process in chronic rhinosinusitis with nasal polyps (CRSwNP) has been extensively studied. However, little is known about the influence of cell death in this disease. Thus, the molecular assessment of mechanisms involved in apoptosis might shed light on the pathogenesis of CRSwNP.

\section{Objectives}

To evaluate the gene expression of different apoptotic factors in patients with nasal polyps and control patients.

\section{Methods}

The mRNA expression of the apoptosis mediators caspases 3,7 , and 9 , and p53 protein was analyzed using qRT-PCR in 25 nasal polyps and 18 control samples.

\section{Results}

We observed significantly lower expression of p53 and caspases 3 and 9 genes in patients with CRSwNP compared to the controls, while caspase 7 expression was similarly expressed in both groups.

\section{Conclusion}

The reduced expression of these apoptosis factors in CRSwNP could be related to higher proliferation and perpetuation of inflammatory cells hindering the control of the disease. A better understanding of the possible influence of apoptosis factors on CRSwNP could be a rationale for future therapies.

'School of Medicine of Ribeirão Preto - University of São Paulo, Ribeirão Preto, Brazil

Full list of author information is available at the end of the article

\section{Author details}

${ }^{1}$ School of Medicine of Ribeirão Preto - University of São Paulo, Ribeirão Preto, Brazil. ${ }^{2}$ School of Medicine of Ribeirão Preto - University of São Paulo, ENT Division, Ribeirão Preto, Brazil. ${ }^{3}$ School of Medicine of Ribeirão Preto University of São Paulo, Biochemistry Department, Ribeirão Preto, Brazil.

Published: 16 July 2013

doi:10.1186/2045-7022-3-S2-020

Cite this article as: Valera et al:: Apoptosis factors caspases and p53 and their impact in chronic rhinosinusitis with nasal polyposis. Clinical and Translational Allergy 2013 3(Suppl 2):O20.
Submit your next manuscript to BioMed Central and take full advantage of:

- Convenient online submission

- Thorough peer review

- No space constraints or color figure charges

- Immediate publication on acceptance

- Inclusion in PubMed, CAS, Scopus and Google Scholar

- Research which is freely available for redistribution 